\title{
ADATOK
}

\section{BEREGVÁRMEGYE FLÓRÁJÁHOZ}

\section{BEITR ÄGE}

\section{ZUR FLORA DES BEREGER COMITATES}

\author{
IR'T'A : - VON : \\ MARGITTAI ANTAL.
}

KÜLÖNNYOMÁS

A “MAGYAR BOTANIKAI LAPOK》 X. ÉVFOLYAMÁNAK 11/12. SZÁMÁBÓL.

SEPARAT-ABDRUCK

AUS No. 11/12. DES X. JAHRGANGES DER «UNGARISCHEN BOTAN. BLÄTTER».

BUDAPEST

PALLAS IRODALMI ÉS NYOMDAI RÉSZVÉNYTÁRSASÁG 



\title{
Adatok Beregvármegye flórájához.
}

\section{Beiträge zur Flora des Bereger Comitates.}

\author{
Irta: Y Margittai Antal (Stubnyafurdö).
}

Mint a munkácsi főgymnázium tanulója már 1896 óta botanizáltam a megyében és azóta is úgyszólván minden évben meglátogattam szülöföldemet, hogy a megye különböző részeit átkutassam floristikai szempontból. Az 1910-11. évi vakácziómat ismét Beregben töltöttem s az alább felsorolt helyeken részint gyüjtögettem, részint összeírtam a czikkembem közölt adatokat. Többször fennjártam a Verchovinán is, de onnan csak azokat az adatokat közlöm, melyeket Tharsz Lajos úr, aki időközben szintén kutatott a megye felvidéki részén, a "Magyar Botanikai Lapok» X. kötet 38-64. lapjain megjelent czikkében fel nem sorolt. A Szinyák hegységböl, ahol Thaisz úr nem botanizált, azokat az adatokat nem sorolom fel, melyekröl Thaisz úr azt mondja, hogy «i n parte superiore ubique» megtalálhatók.

$\mathrm{Az}$ átkutatott területek:

1. Munkács környéke. Ennek a flóráját tudtam legjobban átkutatni, amennyiben, mint a munkácsi gymn. tanulója, tỏbb éven keresztül az év különböző szakaiban volt alkalmam botanikai kirándulásokat végezni. E terület ritkasága az Utricularia vulgaris.

2. A Szinyák hegycsoport. A vulkanikus eredetü és trachit, kőzetből álló hegycsoport alig éri el a 800 m. magasságot. Érdekessége a Radiola linoides, melyet a Szinyák patak mentén, már közel Ungmegyéhez, gyűjtöttem. Valószinüleg elö fog még kerülni a megye más részéböl, sőt talán Ungmegyéböl is, csakhogy eddig kicsinységénél fogva kikerüilhette a botanikusok figyelmét. Ritkaságok még: Dianthus deltoides, Jasione montana és Typha Shuttleworthii.

3. A síkságnak azon része, mely a Sztára patak, a Latorcza, a Szernye-patak és a Kerepecz patak között terül el. Alluvialis terület, melyet sok helyen $4-5 \mathrm{~m}$. magasságú agyag borít. A nagy terület flórája rendkívül szegénynek mondható, mert az igen termékeny földnek minden talpalattnyi részét müvelés alá vették, úgy, hogy flórája árkokba, vasúti töltésekre, mocsarakba és még ki nem irtott erdőkbe húzódott. Ritkaságai : Heleocharis acicularis, Heleocharis carniolica, Portulaca oleracea, Salvinia natans és Urtica kioviensis.

4. Beregszász környéke.

5. A Szernye mocsárnak a Vérke és a Feketevíz közé eső része. Ritkaságok: Elatine Alsinastrum, Polycnemum arvense. 
6. A sík terület ama része, mely a Tisza, a Szernyecsatorna, a Budapest-Lavocnei ronatrész, Kislónya és Mezőkászony közt terül el. Ritkaság: Cicuta virosa.

7. A megre felvidéki része, kivéve a Borlógyilt.

Czikkemben a megyére nézve összesen 408 új adatot sorolok föl. Adataim a következök:

Cystopteris fragitis (L ) Bern. A Viznicze völgyben, Szarvasrét köriil. Nephrodium Filix mas (L.) Rich. Szarvasréten árnyélios erdökben. Polystichum Braunii (Spenx). Braun. Szidorfalva fölött, a Szinyák hegységben.

“ Lonchitis (L.) Rотн. Ugyanott.

Asplenium Trichomanes L. Szarvasréten, a Szinyák hegyesoportban. “ Ruta muraria L. A Várhegy szikláin, Várpalánka melletr. Athyrinm Fitix femina (L.) Roth. A bejárt teriilet erdeiben mindeniitt.

Polypodium vulgare L. A városi erdőben, Munkács mellett; a Szinyák hegyesoportban, Frigyesfalva és Szarrasrét köriil.

Salvinia natans (L.) ALL. Csongor mellett, az ujdávidháziak legelö-

jén és a Feketevízben, Gát mellett: a Kászonyi csatornában;

Bátyú és Barkaszó között a rasúti árokban.

Equisetum arvense L. A sík teriileten mindenïtt.

" hiemale L. Szarvasrét mellett gréren; a Vicsa patak mentén, Zányka körüul: a Lomoványa völgyben, Szarvaslét mellett.

“ limosum L. Iványi és Kílacsány közt, a patak mentén.

" palustre L. Klastrom alján, Nunkács mellett.

Lycopodium Selayo L. A Szinyák hegyesoportban Szarvaslét és Ilgócz környékén.

" clavatum L. A Szinyák hegycsoportban.

Typha latifolia L. A sik teriilet álló vizeiben mindenütt.

" angustifolia L. A Kerepeez csatornában, Várpalánka mel-

lett; a rasúti árokban, Barkaszó és Bátrú között.

"Shuttlexorthii Koch et Soxd. A Szinyák hegységben, a

Cserna patak felsö folrásánál seregesen.

Sparganium ramosum Huds. Ujdáridházán. Csongoron, Bereg-Ardon, Barkaszó és Bátyú között: a Szernıemocsál rizeiben; Iványi és Klácsány köruiul.

" simplex L. Ignécz és Dubróka körüil.

Potamogeton crispus L. A Kerepecz csatornában, Várpalánka mellett; a Czihornyán, Váralja mellett: Beregszászon a Vérliében és a Feketevizben.

Potamogeton lucens. L. A Kaszonyi esatornában, Harangláb mellett. " perfoliatus L. Ugyanutt.

“ natans L. Váralja mellett, a Czihornyában.

“ pusillus L. Ugyanott és Ujdávidháza körül, álló vizekben. 
Alisma Plantayo L. Munkáes, Várpalánka, Várkulesa környékén. $\mathrm{Az}$ Alföld területén, álló vizekben mindenütt.

Sagittaria sagiticaefolia L. A Kerepecz-csatornál)an, Munkács és

Várpalánka között; Iványi és Klacsány között; a Kaszonyi esatornában.

Butomus umbellatus L. A sik teriileten, Csongor mellett; a Fekete-

vízben; Bátyú köriul, a vasuti árokban; Som környékén.

Hydrocharis morsus ranae L. A sik területen, Csongoron, az ujdávid-

háziak legelőjén és Beregszász és Bátyú közt, a vasuti árokban.

Stratiotes aloides L. Bátyú és Barkaszó között. a vasuti árokban. Panicum Crus galli L. A sík terïleten több helyen, így Ujdávidházán, Várpalánkán, Várkulesán.

“ oryzoides ARD. Údávidháza és Rákos mellett, a kukoriczásban; Bátyú mellett.

Digitaria sanguinalis (L.) Scop. A sík terïleten közönséges.

Setaria glauca (L.) BeAuv. A sík teriileten, a Latorcza két partján közönséges.

" verticillata (L.) BEauv. Csak Várpalánka környékén gyéren. Oryza clandestina A. BR. A Kerepecz-csatornában a Nagyhegy alatt, Munkács mellett; Klacsány körül, a Kaszonyi esatornában Harangláb mellett.

Baldingera arundinacea (L.) G. M. ScH. Klacsán körül és a Lovácskán, Munkács mellett.

Phleum nodosum L. A sík területen, Ujdávidháza mellett.

Alopecurus geniculatus L. Ujdávidházán, Pósaházán, Csongoron és

Nagybereg környékén.

Alopecurus pratensis L. A sík terïleten közönséges.

Agrostis vulgaris L. A Szinyák hegyesoport rétjein.

Agrostis alba L. Úgy a sík, mint a Szinyák hegycsoport területén közönséges.

Calamagrostis lanceolata Rотн. A Lovácskán, Munkács mellett. Holcus lanatus L. Várpalánkán a Várhegyen; a Lovácskán, a Pálhegyen és Vereshegyen, Munkács mellett; a Sajgóban;

a Szinyák hegységben.

Phragmites communis Trin. Várpalánkán.

Arrhenatherum elatius (L.) M. et K. A sík teriileten, Ujdávidháza és Csongor mellett.

Molinia coerulea (L.) MNch. A Munkácsot környező szőlöhegyek alatti nedves réteken.

Eragrostis pilosa (L.) Beauv. Ujdávidháza körül, a kukoriczásban; a Vicsavölgyben, a Vócsi-telep mellett.

" minor Host. A Latorcza partján, Ujdávidháza mellett. Sieglingia decumbens (L.) BernH. A Szinyák hegyesoport rétjein szórványosan.

Melica nutans L. Ugyanott.

" ciliata L. A Lovácskán, Munkács mellett, a Nagyhegyen, Beregszász mellett. 
Briza media L. A sík területen közönséges.

Cynosurus cristatus L. A Szinyák-hegycsoportban; a sik területen, a Sajgóban.

Poa annua L. A sik teriileten közönséges.

" compressa L. A sík területen, Ujdávidháza és Csongor körül.

" nemoralis L. A Sajgóban, Pósaháza mellett.

“ pratensis L. A sík területen, Ujdávidháza és Várpalánka körül.

“ tivivialis L. A sík terïleten közönséges.

Glyceria fluitans (L.) R. Br. A sik teriilet vizenyös helyein mindenütt.

“ aquatica (L.) WAHLB. Ujdávidház in.

Festuca rubra L. Szarvasréten, a Szinyák-hegycsoportban.

" pratensis Huds. Csongoron az erdökben.

" gigantea (L.) VILL. Csongor mellett, az ujdávidházai legelön.

Bromus inermis Lerss. A Latoreza-csatoma mentén, Ujdávidháza és Nagylucska között.

" sterilis L. A sík teriileten közönséges.

“ mollis L. Ujdávidháza és Csongor köriil.

“ tectorum L. Várpalánka és Ujdáridháza köriil.

Lolium perenne L. A síkon közönséges.

" temulentum L. Ujdávidházán, vetések közt.

Agropyion caninum Schres. Munkáes és Ujdávidházán, a Latorcza partján.

“ repens L. A Pikujon; Ujjávidháza környékén.

Hordeum murinum L. Klastromalján, Munkács mellett; a Várhegyen, Várpalánkán seregesen.

Cyperus fuscus L. Várpalánkán, az Agasztóföld rétjén.

Cyperus flavescens L. A Szinyák-hegységben, Szidorfalva és Dunkó-

falva köriil.

Scirpus compressus Pers A Szinyák-hegycsoportban, Felsőviznicze és Szarvasrét közti részen.

" lacustris L. Ujdávidháza, Várkulesa környékén.

“ silvaticus L. Ujdávidháza, Várpalánka, Ignécze körül s más helyeken is.

“ Tabernaemontani GuEL. A Feketevizben Gát mellett; a Kaszonyi csatornában: Bátyú és Barkaszó körül.

Heleocharis ovata (Rотн.) R. Br. A Szinyák-völgyben; árkokban Várkulcsa és Barkaszó között.

“ carniolica Косн. Árokban Mezöterebes mellett néhány tövel. acicularis (L.) R. BR. Dubróka körïl és Csongoron, az újdávidházai legelö melletti csatornában.

" palustris (L.) R. BR. A sík teriilet mocsaras helyein mindenuitt.

Carex acuta L. Vál’palánkán, a Kerepecz-csatornában. 
Carex acutiformis Енвн. A Sajgóban, Pósaháza mellett.

“ brizoides L. Mezőterebes és Csongor közti erdőkben; a Szinyák-hegységben.

" Davalliana Sir. A Szinyák-hegycsoportban, Szarvasreét és Felsőviznicze közti réteken.

“ digitata L. Szarvasréten, a Szinyák-hegycsoportban; Ilgóczon. " echinata Murr. Ugyanott.

" flava L. Alsóvizniczén, Felsővizniczén és Szarvasréten, a Szinyák-hegységben.

“ hivta L. Várpalánkán, a Kerepecz-csatornában; Szarvasréten.

" paniculata L. Szarvasréten, a Szinyák-hegycsoportban.

“ remota L. Ilgócz és Szarvasrét közti erdőkben, a Szinyákhegységben.

“ Pseudocyperus L. A sík területen, Bátyú és Barkaszó közt a vasuti árokban.

“ riparia Curt. Várpalánkán, a Kerepecz-csatornában.

" silvatica Huds. Szarvasréten.

“ vesicaria L. Várpalánkán, a Kerepecz-csatornában; a Cserna patak mentén, Szarvasrét mellett.

" vulpina L. A sík terïlet mocsaras helyein.

" vulgaris Fr. A sík területen Szentmiklós körül.

Lemna minor L. Álló vizekben, Várpalánka és Ujdávidháza körül. " trisulca L. A Feketevizben Gát és Nagybereg között; Ujdávidháza mellett álló vizekben.

Spirodela polyrrhiza (L.) Schleid. A Feketevízben, Gát mellett. A sík terület álló, vizeiben gyakori.

Juncus bufonius L. A Kis-Pinye-patak mentén, a Rozgyilán; a Szinyák-hegységben.

" conglomeratus L. Iglóczon és Szidorfalván, a Szinyákhegységben.

“ effusus L. A sík területen, Újdávidháza mellett.

" glaucus Eнrн. Várpalánkán.

“ lampocarpus EnRH. Várpalánkán, a Kerepecz-csatornában. Luzula campestris (L.) DC. A sík területen mindenütt.

" nemorosa $v a$ : cuprina Roch. Szarvasréten, a Szinyákhegységben.

" maxima DC. Ugyanott.

“ pilosa (L.) WILLD. A Szinyák-hegycsoport árnyékos erdeiben.

Veratrum album L A Sajgóban, Várkulesa mellett.

“ Lobelianum BeRNH. Szarvasréten, a Szinyák-hegységben. Colchicum autumnale L. A sík teriileten mindeniitt. Anthericum ramosum L. Munkács mellett, a Lovácskán és Pálhegyen, Beregszász mellett, a Nagyhegyen.

Gagea arvensis (Pers.) R. et Scr. Munkács mellett, a honvédlövöldében. 
Gagea pratensis (Pers.) Reichb. Ugyanott.

“ lutea (L.) KerN. Várpalánkán kertekben.

Allium montanum Schм. Munkács mellett, a Pálhegyen.

"Scorodoprasum L. A sík teriileten és a párkányzó dombokon szórványosan mindenütt.

" ursinum L. A Pikuj havason.

Lilium Martagon L. A sík területen, a Sajgóban, Pósaháza mellett. Fritillaria Meleagris L. A Szernyemocsárban.

Scilla bifolia L. Oroszvég és Frigyesfalva közti erdöben (lusus albus ugyanott.)

Ornithogalum umbellatum L. Munkács és Várpalánka köriil, árkokban.

Muscari comosum (L.) MrL. A Lovácska alatt elteriilő retések között, Munkács mellett.

Majanthemum bifolium (L.) DC. Erdőkben, a Szinyák-hegycsoportban.

Polygonatum officinale AlL. Munkács köriili dombokon.

“ verticillatum (L。) AlL. A Szinrák-hegységben Szarvasréten.

Convallaria majalis L. A Csernekhegyen és Lovácskán, Munkács mellett.

Paris quadrifolia L. A Lovácskán, Munkáes mellett; a sík területen csak Pósaháza és Várkulesa közti erdöben.

Leucojum vernum L. Frigyesfalván a malomnál seregesen terem. “ aestivum L. Váralján árkokban és nedves réteken szórványosan.

Galanthus nivalis L. Klastromalján, Munkács mellett.

Crocus Heuffelıanus Herbert. Munkáes mellett, a honvédlövöldében és a Sajgóban, Pósaháza mellett.

" albiflorus Kir. Mlunkács mellett, a honvédlövöldében szálanként.

Gladiolus imbricatus L. Felsöriznicze és Szarvasrét közti réteken, a Szinyák patak mentén.

Iris Pseudoacorus L. A Kerepecz-csatornában, Munkács és Tárpalánka között; Klacsány és Tárkulcsa köriil.

Orchis latifolia L. A Lovácskán Munkács mellett.

" palustris JACQ. A Lovácska alatti réteken; Pósaháza mellett, a Sajgó szélén.

" maculata L. Nedves réteken, a Szinyák-hegységben.

" militaris L. A Lovácskán.

" Morio L. A Vereshegyen, Munkács mellett.

" sambucina L. A Csernekhegyen, Munkács mellett.

Platanthera bifotia (L.) Rich. A Sajgóban, Pósaháza mellett.

Cephalanthera longifolia (L.) Fritsch. A Lovácskán Munkács mellett.

Epipactis latifolia (L.) AlL. Csongor és Mezöterebes közti erdőkben. 
Epipactis palustris (L.) CR. Szarvasréten, a Szinyák-hegységben. " rubiginosa Gaud. Beregszikláson.

Neottia nidus avis (L.) Rrch. Árnyékos erdőkben, a Csernekhegyen és a Sajgóban.

Populus alba L. Munkács és Ujdávidháza közt, a Latorcza partján.

“ tremula L. A síkság erdeiben szálanként.

" pyramidalis (Roz.) Spach. A sikságon, utak mentén és kertekben.

Salix alba L. A sík terïlet vizei mellett mindenuitt.

" caprea. L. A síkság erdeiben.

«. cinerea L. Közönséges.

" fragilis L. Várpalánka körül.

" viminalis L. Ujdávidháza és Várpalánka közt a Latorcza partján.

" acuminata Sivith. Újdávidházán.

“ triandra L. A Latorcza partján szórványosan, Ujdávidbáza köriül.

Coryllus Avellana L. A síkság erdeiben közönséges.

Betula alba L. Az erdőkben szórványosan.

Alnus glutinosa (L.) DC. Csongor mellett erdőket alkot.

Castanea sativa MrLl. Munkácson, a Pálhegyen; Belegszász mellett, a Nagyhegy erdős részén több példány látszólag vadon nö.

Ulmus campestris L. A sík területen szórványosan.

Humulus Lupulus L. A sík teriileten mindeniitt.

Urtica urens L. Újdávidházán, Várpalánkán kertekben bőven.

" kioviensis Rogow. A Sajgóban nedves, mocsaras helyeken

Várkulesa mellett. Második hazai termőhelye.

Viscum album L. A Lovácskán gyümölesfákon; a sík területen tölgyeken élősködik.

Aristolochia Clematitis L. Ujdávidháza körül vetésekben, réteken seregesen.

Rumex acetosa L. A sík területen mindenütt.

“ Acetosella L. Várpalánkán a legelőn; Ujdávidházán a Latorcza partján.

“ conglomeratus Murr. Várpalánkán.

" crispus L. Ugyanott.

“ obtusifolius L. A Pálhegyen Munkács mellett.

" sanguineus L. A Sajgóban, Pósaháza mellett.

Polygonum aviculare L. A sik teriileten utak szélén, legelökön mindenütt közönséges.

" amphibium L. var. $\beta$ terrestre. A Latoreza-csatorna mentén, Ujdávidháza és N.-Lueska között, vetésekben.

" Convolvulus L. A sík területen, vetések között kellemetlen gyom. A Felvidéken csak Alsóvereczkén gyüjtöttem. 
Polygonum Hydropiper L. Ujdávidházán kertekben.

" lapathifolium L. A sik teriileten mindeniitt közönséges.

“ Persicaria L. Ujdávidháza és Várpalánka kertjeiben.

“ mite Schrk. Várpalánkán, Mezőterebesen s a sil terület más helyein is.

Polycnemum arvense L. Beregszász és Beregardó közt, a vasut mentén; tarlókon Beregrákos mellett.

Chenopodium Bonus Henricus L. A sík területen mindenütt falrak kiörüul.

" album L. A sik teriileten közönséges.

“ hybridum L. A sik területen, Tárpalánkán, Ujdávidházán és Gát köruill.

“ polyspermum L. Ujdáridháza és Várpalánka körül, retések közt közönséges.

" urbicum L. A sik területen, a Latorcza körïli falvak körïl.

Amaranthus retroflexus L. Ujdávidháza és Tárpalánka kertjeiben közönséges.

Salsola Kali L. Bátyún a vasuti állomáson. Talószinüleg a vonattal hurczolták be $\mathrm{s}$ most a homokos pályaudvaron vegetál. Portulaca oleracea L. Ujdávidháza köriil. a kukoriczásban; Munkács és Yárkulesa közütt a vasuti töltésen; Bátyú és Barkaszó köriil.

Agrostemma Githago L. A sik teriileten retések közt.

Tiscaria viecosa (GILIB.) Aschers. A Lovácskán, Munkáes mellett: a

Tárhegyen, Tárpalánka mellett s több helyen a Szinyákhegrségben.

Silene gallica L. Szarvasréten, a Szinyál-hegrségben.

" inflata Sir. A Szinyák-hegrségben több helyen; (lusus roseus).

Ujdávidháza és Tárpalánka között.

" italica (L.) Pers. sep. nemoralis (IV. K.) Williams. Lovácskán Nunkács mellett.

Melandryum album (MrL.) GARcke. A bejárt terïleten közönséges. “ rubrum (WGu.) GARcke. A Lorácskán. Csernekhegren, Munkács mellett: Szarvasréten, a Szinyákhegységben.

Cucubalus baccifer L. Ujdáridházán, Csongoron, Frigyesfalván, Alsórizniczén és Szarvasréten.

Gypsophita muratis L. A sik területen közönséges.

Dianthus Armeria L. A sik teriileten közönséges.

" compactus Kír. $f$. alb. A Temmatik-havas rétjein.

" saxigemus Schur. A Szinyák-hegységben mindenuitt közönséges.

« deltoides L. Frigyesfalva mellett.

Saponaria officinatis L. A Latorcza mentén, a sik területen mindenuitt. 
Stellaria Holostea L. A Várhegyen, Várpalánka mellett; a Sajgóban, Pósaháza mellett; Csongor körül.

" media L. A bejárt terïleten közönséges.

" nemorum L. Szintén.

“ graminea L. Szintén.

“ uliginosa Murr. A Csernapatak mentén, a Szinyákhegységben.

Cerastium vulgatum L. Közönséges a sík területen.

“ arvense L. Munkács körül.

Sagina nodosa (L.) Fenzl. A Tichi-patak tőzeges rétjein, Szarvasrét mellett.

“ procumbens L. Várpalánka, Várkulesa és Ujdávidháza legelöin.

Malachium aquaticum (L.) Fr. A sik területen Mezőterebes és Rákos környékén.

Arenaria serpyllifolia L. A sík területen közönséges.

Moehringia trinerva (L.) CLAIRv. A Szinyák-hegységben mindenütt.

" muccosa L. A Pikuj-havason.

Spergula arvensis y maxima Bönvgh. Szarvasréten és, Szidorfalván; a Szinyák-hegycsoportban; a sík területen, Ódávidháza

és Iványi között a kukoriczásban.

Spergularia rubra (L.) Dum. A sík területen Várpalánka, Váralja, Ujdávidháza és Csongor legelöin.

Scleranthus annuus L. A sik terület legelöin gyakori.

Nuphar luteum (L.) Sm. Ujdávidháza és Klacsány körül álló vizekben.

Ceratophyllum submersum L. Ujdávidházán, a Latorczában; Várpalánkán, a Kerepecz-patakban; a Fekete vízben, Gát körül. Caltha palustris L. A bejárt területen közönséges.

Helleborus purpurescens W. et K. ssp. Baumgartenii Kov. A Szinyák-hegységben, Frigyesfalva körül.

Actaea spicata L. Szarvasréten, a Szinyák-hegységben.

Nigella arvensis L. Mezöterebes és Bátyú körül.

Isopyrum thalictroides L. Klastromalján, Munkács mellett.

Aquilegia vulgaris L. A Várhegyen, Várpalánka mellett.

" " "(lusus albus) Ugyanott.

Delphinium Consolida L. A sík területen vetések közt.

Aconitum rigidum Reich. A Pikujhavason.

" Skerisorae GAy. A Pikujhavason és Szarvasréten a Szinyákhegységben.

" moldavicum Hacqu. A sík területen, a Sajgóban, Pósaháza mellett.

Anemone nemorosa L. A Klastromalján és a honvédlövöldében, Munkács mellett.

“ ranunculoides L. A Szinyákhegységben, Frigyesfalva köriil. 
Clematis recta L. Ujdávidháza és Munkács között, a Latorcza partján; a Lovácskán, Munkács mellett.

“ Vitalba L. A Várhegyen, Várpalánka mellett. Ranunculus acer L. A bejárt területen mindenütt.

" aquatitis L. A Czihornyán, Váralja mellett.

“ arvensis L. Várpalánka és Munkáes közti mezőkön. " aureus Schleich. Klacsány mellett, az erdőben.

" auricomus L. A Sajgóban, Pósaháza mellett.

“ bulbosus L. A Latorcza partján, Ujdávidháza és Várpalánka között.

“ Ficaria L. A sík teriileten csak Tárpalánkán szedtem. " Fiammula L. A sík területen közönséges.

" Lingua L. Barkaszó és Bátyú közt a vasuti árokban. " polyanthemus L. A Szinyák-hegységben szórványosan. " repens L. A sík teriileten közönséges.

" sardous Cr. var.mediterraneus Grises. A sik teriileten Munkáestól délre egészen Mezőterebesig.

Thatictrum aquitegifolium L. A Pikujhavason és a vereczkei szorosban.

lucidum L. Cserjésekben, réteken, árkok szélén a sik teriileten Ujdávidháza, Rákos és Nagy-Lucska körül; Dunkófalván.

Thatictrum galioides NEstL. A legelők szélein Bátyú mellett.

Berberis vulgaris L. Ilgóczon a Szinyákhegységben.

Papaver Rhoeas L. A Tárhegyen, Várpalánka mellett. A sík területen vetések közt.

Chetidonium majus L. A sik területen, falvak körül.

Coryclatis cava Sch. et K. Várpalánkán, a Várhegy alatti kertekben.

“ solida (L.) Su. A Klastromalján, Nunkács mellett.

Fumaria rostellata Kxaf. Beregszász mellett, a Nagyhegyen igen gyéren.

Lepictium campestie (L.) R. Br. At sik teriileten, Várpalánka és Ujdávidháza köruil.

" Draba L. Bátyú és Ilunkács közt a vasut mentén; Várpalánkán a kertekben kellemetlen grom.

" perfoliatum L. Volóczon, a vasuti állomáson.

" ruderale L Várpalánka és Ujdávidháza köriul, kertekben és mezökön.

Thlaspiarvense L. A sík terïleten. Ujdávidháza és Várpalánka körül. Alliaria officinalis Andr. Ugyanott.

Sisymbrium Sophia L. Ujdávidházán kertekben.

" officinale Scop. Ugyanott a Latorcza partján.

Sinapis arvensis L. A bejárt területen mindenütt bőven.

“ orientalis Murr. Ujdávidházán, retések között gyéren. Diplotaxis muralis(L.) DC. Ujdávidházán a Latorcza partján; Tárpalánkán a Várhegyen; Szarvasréten a Szinyák-hegységben. 
Raphanus Raphanistrum L. Várpalánkán, Szarvasréten vetések közt.

Barbarea arcuata (OpIz) Rегснв. A sík területen, Ujdávidháza környékén a kukoriczásokban.

" vulgaris $\mathrm{R}$. BR. A sík területen közönséges.

Nasturtium officinale $\mathrm{R}$. BR. Munkács mellett, a Latorcza partján.

" Armoracia (L.) F. Schultz. Nagy-Lucska, Ujdávidháza, hiresek a tormáiról.

" silvestre (L.) R. Br. A sik területen mindenütt.

" austriacum Cr. Ujdávidháza, a Latoreza partján.

Cardamine silvatica L. Szarvasréten és a Pikujhavason.

" pratensis L. A bejárt területen mindenütt.

Dentaria bulbifera L. Munkáes körül, erdőkben.

Capsella bursa pastoris (L.) Мксн. A területen mindenütt.

Draba verna L. Munkács körül.

Neslia paniculata (L.) Desv. Munkács és Várpalánka körül, a vetésekben.

Arabis arenosa (L.) Scop. Munkács körül.

" glabra (L.) Weinм. A Vereshegyen, Munkács mellett; Ilgóczon, a vágásokban.

Erysimum cheiranthoides L. A sik területen, a Latoreza körüli kukoriczásokban.

“ pannonicum CR. Várpalánka körül.

Bunias orientalis L. A sík területen, Várpalánka körül.

Alyssum calycinum L. Szarvasréten.

" desertorum STAPF. Várpalánkán, a Várhegyen.

Reseda lutea L. Ujdávidháza és Munkács körïl.

Drosera rotundifolia L. A Cserna- és Tichi-patak tözeges helyein,

a Szinyák-hegységben.

Sedum acre L. Várpalánkán és Beregszász körül.

" boloniense Lors. Ilgóczon, a vágásokban.

" maximun L Várpalánka mellett, a Várhegyen; a Csernekhegyen, Munkács mellett; a Nagyhegyen, Beregszász mellett.

" carpaticum Reuss. A Temnatik havasnak Zánykafürdő felé eső részén.

" glaucum W. et K.f. glanduloso-pubescens Feicht. A Vereczkei szoros szikláin, a Latorcza folyó mentén.

Sempervivum tectorum L. Házak tetején, Várpalánkán és Váralján. Saxifraga bulbifera L. A Szarkahegyen, Hegyöralja mellett.

Ribes grossularia L. Szarvasréten, a Szinyák-hegyesoportban. Aruncus silvester Kostez. Ugyanott.

Filipendula ulmaria (L.) Maxın. Ugyanott.

" hexapetala Gitıs. A sik teriileten, Várpalánka és Ujdávidháza környékén.

Pirus communis L. A bejárt területen szétszórva.

" Malus L. Szintén. 
Sorbus aucuparia L. Szarvasréten.

“ aria (L.) Cr. Beregszász, Munkáes környélzén.

Rubus bifrons T'Est. A Lovácskán, Munkács mellett; a legelökön Iványi mellett.

“ glandulosus BeLl. Várpalánkán, a Várhegyen.

“ caesius L. Ugyanott.

“ idaeus L. Vágásokban, a Szinyákhegységben.

Fragaria vesca L. A bejárt terïleten közönséges.

Potentilla alba L. A Csernekhegyen és Pálhegyen, Munkács mellett.

" anserina L. A sik teriileten is mindeniitt.

“ argentea L. A sík teriileten, Ujdávidháza köriil réteken.

" aurea L. A Pikuj havason.

“ recta L. Ḱlacsány és Iványi fölötti szőlöhegyeken;

Ujdávidháza köriil réteken.

“ reptans L. Várpalánka köriul.

" silvestris Neck. A Szinyákhegységben és a sikon is mindeniitt.

Geum urbanum L. A sikságon közönséges.

Agrimonia eupatoria L. A sikságon réteken, árkokban mindenütt. Aremonia agrimonoides (L.) Neck. Nezöterebes és Csongor közt az

erdőben. A Sajgóban, Pósaháza és Várkulesa mellett selegesen.

Sanguisorba minor Scop. Munkáes és Várkulesa között, a rasuti töltésen.

" officinalis L. A sik teriilet rétjein közönség’es.

Prumus spinosa L. A sík teriileten közönséges.

Rosa canina L. $t$. nitens Desv. Csongor mellett, az ujdávidházaiak legelöjén.

“ « L. f. aciphylla Liñ. Ujdávidházán a legelön.

" coriifolia Fr. Csongor mellett, az ujdáridházaiak legelöjén.

“ dumetorum Tн. f. platyphyyllos Desv. A Pálhegyen, Munkács mellett.

“ yallica L. Iványi fölött a szölöhegyeken: a Nagyhegyen Nunkács mellett.

“ squarrosa Rav. Ujdávidházán a legelön.

Genista germanica L. Munkács köriili szölöhegyeken, Felsövizniczén, Ilgóczon, a Szinyálkhegységben, Beregszász mellett, a Nagyhegyen.

" tinctoria L. A bejárt teriileten mindenüitt.

“ pilosa L. Munkács és Hegyőralja köruili dombokon.

Cytisus serotinus Kiт. I hó fölött a szőlőhegyeken; a Lovácskán,

Cselnekhegyen és Pálhegyen Munkács mellett; a Nagyhegyen, Beregszász mellett.

" nigricans L. A Szinyálihegységben.

Sarothammus scoparius (L.) Wrnı. A Lovácskán, Munkács mellett;

Dunkófalván. 
Ononis hircina JACQU. A sík területen közönséges.

" " " (usus albus) Ujdávidházán.

“ spinosa L. Munkács körül, a kaszálókon, de jóral gyérebben az elöbbinél.

Anthyllis vulneraria L. A sík teriileten.

Trifolium agrarium L. Ujdávidháza köriil.

" alpestre L. Szarvasréten, a Szinyákhegyesoportban.

" arvense L. A sík terïleten, retések közt.

" aureum PolL. A sík területen mindenütt.

“ fragiferum L. Felsővizniczén, Szarvasréten, a Szinyákhegységben, a sík területen; Ujdávidházán; Mezőterebesen és Csongoron.

" hybridum L. A sík terïleten szórványosan.

" medium L. Ujdávidházán; Klacsán köriil; a Lovácskán Munkács mellett.

" minus Sir. A Szinyák-hegységben, Felsőviznicze körül; a sík teriileten: Várpalánka, Bátyú, Som, Harangláb és Kislónya környékén.

- ochroleucum L. Ugyanott és a Szarvasréten a Szinyákhegységben.

" rubens L. A Lovácskán, Csernekhegyen és Pálhegyen, Munkács mellett.

Medicago falcata L. A bejárt területen mindenütt.

" sativa L. Szintén.

“ varia MED. (falcata $\times$ sativa) Ujdávidházán, a Latorcza partján.

" lupulina L. Közönséges a bejárt területen.

“ Willdenowii BöNvgh. Ujdávidházán, a temetőben és a Latorcza partján.

Dorycnium herbaceum ViLL. Ujdávidházán, a sík területen mindenuitt.

Melilotus albus Desv. A sik teriileten mindenütt.

" officinalis L. Szintén.

Lotus corniculatus L. A Szinyákhegységben.

“ tenuifolius L. A Pálhegyen és a Csernekhegyen, Nunkács mellett; Rákos környékén.

Galega officinalis L. A sík teriileten s azt környezö dombokon szórványosan mindenuitt.

Astragalus cicer L. Ujdávidházán.

" glycyphyllos L. A Szinyák-hegységben szórványosan és Munkácsot köruilvevö szőlöhegyeken; a sik teriileten a Sajgóban, Várkulesa mellett.

Coronilla vaginalis Lam. A Lovácskán, a Pálhegyen, Munkács mellett.

“ varia L. A bejárt terïleten szólványosan.

Hippocrepis comosa L. A Pálhegyen Munkáes mellett.

Vicia cassubica L. Klacsány körïil. A sik teriileten mindeniitt. 
Vicia Cracca L. A sikon közönséges.

" hirsuta (L.) Косн. Ujdáridháza köriil, vetésekben.

" pannonica Cr. Nezöterebes és Gorond köriil.

" pisiformis L. A Lovácska tetején, Munkács mellett; a szőlöhegyeken Lohó és Iványi fölött.

“ sativa L. A sík teriileten elvadulva mindeniitt.

" segetalis Thulll. A Latoreza partján, Ujđávidháza és Várpalánka között.

“ sepium L. Ujđávidházán, Munkáes köriil, bokrok közt.

" silvatica L. Klacsány melletti erdỏben.

“ sordida W. et $\mathrm{K}$. Csak Csongor mellett gyüjtöttem.

" tetrasperma (L.) Мксн. A bejárt teriileten vetések közt mindenütt.

" villosa Roтн. A sík teriileten, Munkács köriil.

Lathyrus hirsutus L. Ujdávidháza kiörnyékén.

" matensis L. A síkságon mindeniitt.

" silvestris L. Ujdávidháza köriil boklok közt; a Latorcza partján, Ujclávidháza és Várpalánka közt.

“ platyphyjlos Retz. Ugyanott az elöbbivel keverten.

“ tuberosus L. A sikon szórványosan mindeniitt.

"vermus (L.) BERn. A Csernekhegyen, Munkács mellett. Pisum sativum L. Tetések közt, Ujdávidházán és Szarvasiéten.

" arvense L. Ugyanott.

Geranium columbinum L. Yárpalánka és Mlunkács köriil.

palustre L. A Pálhegyen, Munkács mellett.

jihaeum L. Várpalánkán. a Várhegyen.

" matense L. A Vizniczevölgyben.

" Robertianum L. A síz teriileten Várpalánka és Munkács köriil.

" pusillum L. Tárpalánka és Ujuávidháza köriil. sanguineum L. A Pálhegyen, Vunkács mellett.

"siliaticum L. A Szinyák-hegységben.

Erodium cioutarium (L.) L'Hésit. A sik teriileten mindeniitt.

Oxal is Acetosella L. Szintén.

" stricta L. Ujdáridháza és Mezöterebes köriil kaszálókon. Linum catharticum L. A bejált teriileten mindenüitt.

" gallicum L. Iványi köriili réteken igen gyéren.

" usitatissimum L. Elvadulva retések bözött, Szarvasréten.

Radiola linoides Gusel. A Szinyákhegységben, Felsővizniczén a

falusi temetöben seregesen terem.

Polygala amara L. Szarrasréten, a Szinyák-inegységben.

"vulgaris L. Közönséges a bejárt teriileten.

" « "f.oxyptera Reıнnв. Szarvasrét és Felsőviznicze kö:t, a réteken.

“ major JAcQu. A Lovácskán, Munkács mellett. Euphorbia Cyparissias L. A sik teriilet legelöin nagyon kellemetlen gyom. 
Euphorbia Esula L. Várpalánka és Ujcávidháza körïl.

“ helioscopia L. Várpalánka és Ujdávidháza rétjein, szántóin közönséges.

“ platyphylla L. Ujdávidházán. A bejárt teriileten szórványosan mindenuitt.

" polychroma Kerv. A Lovácskán, Munkács mellett.

“ villosa W. et K. A Vizniczevölgyben, Felsőviznicze mellett.

Mercurialis perennis L. A Szinyákhegységben, Szarvasrét köriil. Callitriche verna L. Álló és csendesen folyó vizekben közönséges;

a Pikuj havason c. $1300 \mathrm{~m}$. magasságban is megtaláltam egy forrásban.

Evonymus europaea L. Ujdávidháza és Válpalánka körüil.

Impatiens nolitangere L. A Sajgóban, Pósaháza mellett.

Rhamnus cathartica L. Bokros helyeken, a sík területen.

“ Frangula L. Várpalánkán, a Várhegyen.

Parthenocissus quinquefolia (L) PLANch Ujdávidháza és Várpalánka körül elvadulva.

Tilia parvifolia Eнrн. Munkácson.

“ platyphylla Scop. Várpalánkán.

Malva neglecta WALLR. Ujdávidházán kerítések köriil.

“ pusilla Sм. Várpalánka köriil.

“ silvestris L. A sík területen Munkács és Várpalánka környékén.

Althaea officinalis L. Ujdávidházán, az uj temető körül; Várpalánka és Ujdávidháza közt a Latorcza partján; Som körüil, a legelökön.

Hypericum hirsutum L. Mezőterebes és Csongor közt, az országút mentén.

" humifusum L. @ Liottardi VILL. Iványi körül, a legelökön.

" maculatum CR. A sík teriileten Barkaszó és Mezőterebes között.

« montanum L. Klacsán melletti erdőben; a Lohó fölötti szőlőkben.

" perforatum L. A bejárt területen közönséges.

" quadrangulum L.ASajgóban, Pósaháza mellett; Szarvasréten, a Szinyákhegységben.

" acutum Мксн. Csongoron és Várkulcsán az erdőkben; a Lomoványa völgyben, Szarvasrét köriil.

Elatine Alsinastrum L. Beregszász és Ardó között a vasuti árokban.

Helianthemum obscurum Pers. Beregszász köriil, a Nagyhegyen.

Viola canina L. A bejárt teriileten közönséges.

" hirta L. Munkács köriil a mezőkön.

" silvestris L. Szarvasréten.

" saxatilis Schm. Ugyanott. 
Viola persicifolia Rотн. Bátyú és Harangláb környékén, nedves réteken.

" odorata L. Várpalánkán, a Várhegyen.

“ tricolor L. A bejárt területen mindeniitt.

Daphne Mezereum L. Az erdőkben szórványosan mindeniitt.

Peplis Portula L. Csongoron, az ujdávidházaiak községi erdejébミn; Bereg-Ardón, a vasuti árokban.

Lythrum Hyssopifolia L. Ujdávidházán; Csongor és Beregszász köriil; Várkulesán és Odávidházán, az út mentén.

" Salicaria L. A sík területen közönséges.

“ virgatum L. Várkulcsa, Rákos és Gajdanó nedves rétjein.

Epilobium hirsutum L. Buboliska köriil, az erdöben.

" palustre L. A Szinyákhegységben mindeniitt.

" montanum L Szarvasréten, a Szinyákhegységben.

" parviflor um Schreb. Várpalánkán. A sík teriileten mindeniitt.

" rosmarinifolium HaExke. Csak Frigyesfalva körïl gyüjtöttem.

Chamaenerium angustifolium. (L.) S'Cor. A vágásokban, a Szinyákhegységben mindeniitt.

Oenothera bienmı L. Munkáestól délre egészen Nagy-Iucskáig, a Latorcza partján.

Circcea lutetiana L. Tárpalánkán kertekben, a sík teriilet erdeiben mindeniitt.

Myriophyllum verticillatum L. A Kerepeczcsatornában, Yárpalánka mellett, a Latorcza folyóban szórványosan.

Hedera Helix L. Munkácsot környezö dombokon közönséges.

Sunicula europaea L. A sík teriilet erdeiben, Pósaháza, Várkulesa,

Nezöterebes és Csongor köriil.

Astrantia major I. Szarvasréten, a Szinyákhegységben.

Eryngium campestre L. Ignécze és Beregszász köriil.

planum L. Beregszász mellett, a Nagrhegyen: a Szernye mocsár környékén.

Cicuta virosa L. A vasuti árokban, Barkaszó és Bátyú között. Aegopodium Podagraria L. A sik teriileten mindeniitt.

Carum carvi L. A sík teriuleten, Várpalánkán kertekben; a Szinyákban mindenütt.

Pimpinella magna L. A sík területen szórványosan.

" saxilraga L. Szarvasréten, a Szinyákhegységben.

Sium latifolium L. A sík teriileten, Várkulcsa mellett az erdöben;

Nezöterebes köriil, az országut árkában

Bupleurum longifotium L. Beregszikláson, a Pikuj alatt.

" tenuissimum L. Bátyú, Som, Harangláb és Kislónya közti legelökön.

Oenanthe aquatica (L) Là. Ujdávidháza, Várkulcsa, Nezöterebes környékén árkokban; a Sajgóban Pósaháza mellett. 
Oenanthe banatica Heuff. A sík teriileten; a Kerepecz-csatornában, Várpalánka mellett; Váralja és Pósaháza környékén, nedves réteken és árkokban.

Aethusa Cynapium L. Kertekben, vetések között a sík teriileten. Seseli annuum L. A Nagyhegyen, Beregszász mellett.

" glaucum L. A Pálhegyen, Munkács mellett.

Silaus selinoides (JACQU.) BECK. A Nagyhegyen, Beregszász mellett.

Angelica silvestris L. A sík teriulet nedves rétjein; a Pálhegyen, Munkács mellett.

Anethum graveolens L. Várpalánkán, a Várhegyen elvadulva. Peucedanum Cervaria (L.) CAss. A Pálhegyen és Csernekhegyen, Munkács mellett; a szőlőhegyeken Lohó fölött.

" Oreoselinum (L.) Mrch. A Szinyákhegységben, Felsőviznicze és Szarvasrét között.

“ palustre (L.) Mnch. Mezőterebes, Bátyú és Várkulcsa köruil, nedves helyeken.

" Carvifolia Vill. A Nagyhegyen, Munkács mellett.

Pastinaca satira L. A sík területen mindenütt.

Heracleum Sphondylium L. A teriileten közönséges.

Tordylium maximum L. Várpalánkán, a Várhegyen.

Laserpitium latifolium L. Munkács körül a szölöhegyeken.

Daucus carota L. A sík területen mindenütt gyakori.

Torilis anthriscus (L.) GMeL. A Szinyákhegységben; a síkon is. Anthriccus scandix (Scop.) BEck. A Várhegyen, Várpalánka mellett.

" silvestris (L.) HoFfm. A területen közönséges.

Chaerophyllum aromaticum L. Várpalánkán, Ujdávidházán kertekben.
“ bulbosum L. Ujdávidházán, árkok szélén; Várpa- lánkán, a Várhegyen.
" Cicutaria Vill. A Szinyákban közönséges.

Conium maculatıim L. Ódávidházán; Várpalánkán, a Várhegyen. Pleurospermum austriacum HoFrm. A Pikuj havason.

Cornus mas L. A Klastrom alján, Munkács mellett.

" sanguinea L. A Munkácsot környező dombokon; a sík erdeiben szórványosan.

Pirola uniflora L. A Zsarnóban, Munkács mellett.

" rotundifolia L. Szarvasréten, a Szinyákhegységben.

Monotropa hypopitys L. Beregszikláson, Felső Kisbisztrán a Pikuj-

havas alatt; Szarvasréten, a Szinyákhegységben; a sík terii-

leten a Sajgóban, Várkulesa mellett.

Primula acaulis L. A honvédlövöldében, Munkács mellett.

Soldanella hungarica Simk. A Pikuj havason, a Schönborn havasın, a Temnatikon.

Hottonia palustris L. Váralján, Várpalánkán árkokban; a Sajgóban, a Veres koresma környékén; Mezöterebes és Csongor közt az erdőben. 
Lysimachia nummularia L. A bejárt területen mindenütt.

" punctata L. A sík területen mindeniitt.

" vulgaris L. Ujdávidházán; a várkulcsai erdőben; Klacsány környékén.

Anagallis arvensis L. A sík területen mindenütt közönséges.

Fraxinus excelsior L. Várkulcsa mellett erdőt alkot.

Ligustrum vulgare L. A szőlöhegyek alján, Lauka és Lohó között.

Erythraea Centaurium (L.) PERs. A bejárt terïleten mindenütt.

" pulchella (Sw.) Fr. Ujdávidháza, Nagy·Lucska és Mezöterebes környékén, tarlókon.

Gentiana asclepiaclea L. $f$. alb. A Szinyákhegységben réteken,

Dubina fölött.

Menyanthes trifoliata L. Iványi és Klacsány közt, a patak mentén elteriilő ingoványos réteken.

Tinca minor L. Iunkács környékén; Várpalánkán kertekben.

Cynanchum Vincetoxicum (L.) R. Br. A bejárt teriileten mindeniitt.

“ laxum Bartu. A Nagyhegyen, Beregszász mellett. Convolvulus arvensis I. A sík teriileten retések közt közönséges.

Calystegia sepium (L.) R. Br. Várpalánkán és Ujdávidházán, a Latorcza partján.

Cuscuta europaea L. Felsőkisbisztrán csalánon; Ujdávidházán.

“ Trifolii BAB. A sík terül ten a hatóság nembánomsága és a nép tudatlansága miatt nagy pusztítást végez a lóherésekben.

Cynoglossum officinale L. A Ksarnóban Munkács mellett; a sík teriileten Bátyú, Bótrágy és Harangláb közti legelökön.

Lappula echinata Gilis. Frigyesfalván; a Nagyhegyen, Beregszász mellett igen gréren.

Asperugo procumbens L. Bátyú és Barkaszó között, a vasuti töltésen.

Symphytum officinale L. A sík teriileten közönséges.

a közt a mezökön.

« tuberosum L. A V'ereshegyen, Munkács mellett.

Anchusa officinalis L Ujdávidháza és Váralja közt, a Latorcza partján.

Nonnea pulla DC. Ujdávidháza környékén.

Pulmonaria mollissima KEnn. Klacsány melletti erdöben.

“ officinalis L. A Munkácsot környezö erdőkben közönséges.

Myosotis arvensis (L.) HiLl. A Nagyhegyen, Beregszász mellett.

" sparsiflora Mıкán. Várpalánka, Munkács és Ujdávidháza körül.

“ silvatica Hoffn. A Szinyák-hegységben.

« stricta L. Munkács és Ujdávidháza környékén. 
Myosotis palustris (L.) Laм. f. scabra Suk. Szarvasréten, a Szinyákhegycsoportban; a Nagyhegy alatt, Munkács mellett.

Lithospermum arvense L. Munkács körül, a mezőkön.

Cerinthe minor L. Ugyanott.

Verbena officinalis L. A sík terïleten mindenütt.

Ajuga genevensis L. A honvédlövöldében, Munkács mellett.

" reptans L. A bejárt terïleten közönséges.

“ " " (lusus albus). A honvédlövöldében, Munkács mellett.

Scutellaria galericulata L. Felsövizniczén, a Szinyákhegységben ; a sík területen, Ujdávidháza és Várkulesa környékén.

" hastifolia L. A sík terïleten közönséges.

Nepeta pannonica L. Rákócziszálláson és Felsővereczkén, a Latorcza mentén; Volócz mellett.

“ Cataria L. Ujdávidházán, a legelőn

Glechoma hederacea L. A bejárt területen közönséges.

Prunella grandiflora (L.) JAcoU. A Nagyhegyen, Beregszász mellett. " laciniata L.Kajdanó, Frigyesfalva, Felsőviznicze és Szarvasrét környékén.

Melittis Melissophyllum L. A Lovácskán, Munkács mellett.

Phlomis tuberosa L. Ujdávidházán; a Lovácskán, Munkács mellett. Galeopsis angustifolia Eнrн. A Pálhegyen, Nunkács mellett; a sík területen szórványosan.

« Ladanum L. Az elöbbivel.

“ pubescens Bess. Várpalánkán.

« speciosa Mill. Ujdávidháza, Várkulesa és Szarvasrét körül.

Lamium album L. A sík területen közönséges.

“ amplexicaule L. Szintén.

“ luteum (Huds.) Krock. A Klastromalján, Munkács mellett.

" purpureum L. Mindenütt közönséges.

Leonurus Cardiaca L. A bejárt területen mindenütt.

“ Marrubiastrum L. Ujdávidházán és Várpalánkán, kertekben, kukuriczásokban.

Ballota nigra L. Ujdávidháza.

Stachys alpina L. Szarvasréten és Pikuj havason.

" officinalis (L.) Trev. A bejárt terület rétjein.

" palustris L. Szintén.

“ recta L. A Lovácskán, Munkács mellett. Ujdávidházán vetések közt.

" silvatica L. A Szinyák-lıegységben, Szarvasrét körül; a síkon, Ignécze mellett.

Salvia glutinosa L. A Szinyák-hegységben.

" pratensis L. A sík területen Munkács és Várpalánka körül.

“ silvestris L. Várpalánkán.

“ verticillata L. Várpalánkán; a síkon közönséges.

Satureia Acinos (L.) Schecle. Várpalánkán, a Várhegyen; Beregszász mellett, a Nagyhegyen. 
Satureia vulgaris (L.) Fritsch. Ujdávidházán, a legelön. Hyssopus officinalis L. Várpalánkán, a vár falain, bástyáin elvadulva.

Origanum vulgare L. Várpalánkán, a Várhegyen; Munkácsot környezö dombokon.

Origanum vulgare L. (lusus albus). Várpalánkán, a Várhegyen. Thymus collinus M. B. Ujdávidházán.

" ovatus Mill. $f$. subcitratus Schreb. Szarvasréten. Lycopus europaeus L. A bejárt terïleten közönséges.

Mentha arvensis L. Ujdávidháza köriil tarlókon.

" aquatica L. Úgyanott árkokban; Bátyú és Som között, a vasuti árokban.

“ austriaca JAcQu. Ujđlávidházán, kertekben és a Latorcza partján.

" mollissima Borkн. iar. retinervis (BonB.) Ujdávidháza mellett.

" longifolia Huns. var. discolor (OpIz.) Ugyanott.

" " " virgultorum DESÉGL. $t$. cinerula $\mathrm{H}$.

Braux Nagylueska köriil.

"Pulegium L. A sík terileten közönséges.

Lycium vulgare Dus. Munkácson.

Atropa Belladonna L. A Szinyákhegység vágásaiban.

Scopotia carniotica JACQU. Klastromalján, Munkács mellett.

Hyoscyamus niger L. A sík teriilet falvai köriil és legelöin.

Physalis Alkekengi L. Tárpalánkán, a kertekben és a temetöben. Solanum Dulcamara L. A sik teriileten mindeniitt.

" nigrum L. Ugyanott.

“ villosum La». Várpalánkán, a szölö alatti kertekben.

Datura stramonium L. Várpalánkán és Ujdávidházán, a legelökön közönséges.

Verbascum Blattaria L. A sik teriilet legelőin és rétjein közönséges.

nigrum I Ujdávidházán, a Latorcza partján; a teriileten szórványosan mindeniitt, de jóval grérebben, mint az elöbỉi.

" phlomoides L. A Csernekhegyen, Munkács mellett.

" phoeniceum L. Tárpalánkán, a kertekben, a Pálhegyen, IIunkács mellett.

"Thapsus L. Várpalánkán, a Várhegyen.

" thapsiforme SchraD. Az Alföldet szegélyező dombokon mindeniitt.

Kickxia Elatine (L.) Dum. Ujdávidháza, Nagy-Lucska és Mezöterebes körüil, tarlókon.

Linaria vulgaris MiLL. A bejárt terïleten mindenüitt.

"

" (cum peloria) Ujdávidházán, a legelőn a töalak társaságában találtam. Halványabb, szinte fehérnek mondható szine által vonja magára az ember 
figyelmét. Példányaim között vannak átmeneti alakok is egy- és kétsarkantyús virágokkal ugyanazon példányon. Ezeknek a szine is átmeneti. Egynéhány példányon az oldalsó két sarkantyú kicsiny az eredeti középsőhöz képest. Az egyik példányon öt sarkantyút találtam. A hely, ahol a peloriús Linariát találtam, kövér, de a jószágtól nagyon összetaposott talaj volt.

Antirrhinum majus L. Várpalánkán, a vár bástyáin és falain kiilönböző színkeverékben elvadulva.

«

Orontium L. Frigyesfalván; Beregszász mellett, a Nagyhegyen. Mind a két helyen csak szálanként.

Chaenorrhinum minus (L.) LGE. Vócsitelepen és Volóczon az állomáson.

Scrophularia nodosa L. A bejárt teriileten szórványosan.

" Scopolii Hoppe. Ujdávidházán a legelön.

Gratiola officinalis L. A sík területen közönséges.

Veronica arvensis L. Várpalánkán és Ujdávidházán.

" austriacn L. A Pálhegyen Munkács mellett.

" Beccabunqa L. A sik teriulet árkaiban mindenütt.

" Chamaedrys I. Szintén.

" elatior Eнrн. A Pálhegyen, Nunkács mellett.

" montana L. Csongoron az erdöben.

« officinalis L. A bejárt terület erdeiben.

" orchidea $C_{R}$. A Pálhegyen, Munkács mellett; a Nagyhegyen Beregszász mellett.

" spicata L. Munkácson, a szölőhegyeken; Váralja körül, a Nyirses dülöben.

“ polita Cr. Ujdávidházán vetések közt.

" persica Porr. Váralja és Ujdávidháza körül.

“ scutellata L. Ujdávidháza és Csongor körül, árkokban, nedves réteken; Bátyú és Som körül, a legelökön.

“ serpyllifolia L. Ujdávidházán; Szarvasréten, a Szinyákhegységben.

Digitalis ambigua Murr. A sík területen a Sajgóban.

Melampyrum arvense L. A sík terület vetéseiben.

“ nemorosum L. A Pálhegyen, Munkács mellett.

Euphrasia Rostkoviana HAyne A bejárt hegyvidéken.

Odontites pratensis WintG. Ujdávidháza és Mezöterebes köruil, a tarlókon; Beregszász mellett, a Nagyhegyen.

Alectorolophus major (Енгн.) Rегснв. A bejárt területen közönséges. Lathraea squamaria L. A honvédlövöldében, Munkács mellett.

Utricularia vulgaris L. Munkácson, a Pálhegy alatti vályogvetöben.

Plantago lanceolata L. A bejárt területen közönséges.

" major L. Szintén.

" medic L. Szintén.

Sherardia arvensis L. Ujdávidházán, vetések közt. 
Asperula cynanchica L. A Klastromalján, Munkáes mellett; Szarvasréten, a Szinyákhegységben.

“ glauca (L.) Bess. A Pálhegyen, Munkács mellett.

“ odorata L. A sík terület erdeiben.

Galium Aparine L. Ujdávidházán, a temetőben.

“ Cruciata (L) Scop. A Nyirses diilöben. Váralja mellett.

“ palustre L. Mezöterebesen és Tárpalánkán a sík területen.

“ Schultesii Vest. Klastromalján, Munkács mellett.

Sambucus Ebulus L. Várpalánkán, a Várhegyen, a Latorcza mentén, mindeniitt kellemetlen gyom.

“ racemosa L. A Szinyáklıegységben, Szarvasrét körül.

“ nigra L. A bejárt teriileten mindeniitt.

Viburnum Lantana L. A Sajgóban, Pósaháza körül

" Opulus L. Munkáes köriil.

Valerianella coronata (L) DC. Ujdávidházán, vetések kiözt. Ritka.

“ olitoria (L.) PoLL. A Várhegyen, Várpalánkán.

Dipsacus Fullonum L. Ujdávidházán: Beregszász köriil.

" pilosus L. Ujdávidházán a temetőben.

Succisa pratensis Мксн. A Szinyákhegységben, Szarvasréten és Felsővizniczén; Beregszentmiklós köruil.

" inflexa (Ḱ luck.) Br.ck. Ujdávidháza körïl; a Sizernye mocsárban; a sík teriileten árkokban szórványosan mindeniitt.

Knautia arvensis L. var. polymorpha (Sснм.) Szr. f. agrestis (Sснм.) Sz13. Szarvasréten, a Szinyákhegységben; $f$. glandulosa Froes. Szarvasréten és Kilacsány köriil; Szarvasréten, a Szinyákhegységben.

" silvatica Duby var. dipsacifolia (Host) Godet $t$. vulgata

KrTteL. Szarvasréten a Szinyákhegységben ; var. pocutica

Szzi. A Pálhegyen Munkács mellett.

Scabiosa ochrnleuca L. Várkulesa mellett, a vasuti töltésen; Ignécze köriil.

Bryonia alba L. Beregszász mellett, a Nagyhegyen; Várpalánkán és Ujdávidházán kerítéseken.

Campanula bononiensis L. A Lovácskán, Iunkács mellett; a Nagyhegyen, Beregszász mellett.

« cervicaria L. A Lovácskán, Munkács mellett.

" glomerata L. Ugyanott.

" Tatifolia L. Csongor mellett. az erdöben.

" persicifolia L. A bejárt teriilet rétjein mindenütt.

" rapunculoides L. A honvédlövöldében, Iunkács mellett.

“ rotundifolia L. A Pikuj havas legmagasabb esúcsának sziklahasadékaiban.

" patula L. À bejárt terület rétjein mindenütt.

" " (Cusus cibus) Beregszikláson, a Pikuj alatt. 
Campanula Trachelium L. A sík területen, Csongor mellett. Adenophora infundibuliformis DC. A Nagyhegyen, Munkács mellett.

Phyteuma spicatum L. ssp. ochroleucum DöLL. var. cordifolium Wallr. A Szinyák-hegységben, Szarvasrét mellett.

“ orbiculare L. A Szinyák-hegységben.

Jasione montana L. Felsővizniczén, Ilgóczoll. a Szinyákhegységben; a síkon lejön egész Várkulcsáig.

Eupatorium cannabinum L. A bejárt terïleten közönséges.

Sotidago canadensis L. Várpalánka és Ujdávidháza közt, a Latorcza partján.

“ Virga aurea L. A sík területen, a Latorcza mentén. Bellis perennis L. A bejárt terület legelőin mindenüitt.

Aster Linosyris (L.) Berni. Szerednye környékén, napos hegyoldalakon; a Nagyhegyen, Munkács mellett.

Stenactis bellidiflora A. BR. A síkságon s a hegyekbe nyúló völgyekben közönséges.

Erigeron canadensis L. A sik területen, a Latorcza mentén.

Trimorpha acris (L) Vienhapper. A bejárt területen közönséges. Filago arvensis L. A Nagyhegyen, Beregszász mellett, a Pálhegyen és Lovácskán Munkács mellett

" germanica I. Ilgóczon, a Szinyákhegységben.

Antennaria dioica Gärts. A Lovácskán, Munkács mellett.

Gnaphalium silvaticum L. A Pálhegyen, Munkács mellett.

". norvegicum Gun. A Pikuj havason.

" uliginosum L. A sík területen mindenütt.

Inula britannica L. A Nagyhegyen, Beregszász mellett; a sík teriileten, Mezöterebes körül.

" ensifolia L. Ugyanott.

“ Helenium L. A Nagyhegy alatti kaszálókon, Munkács mellett.

“ Conyza DC. Frigyesfalva és Szentmiklós körül, az erdő szélén.

" salicina L. Beregszász mellett, a Nagyhegyen; Ujdávidházán, a legelön.

Pulicaria vulgaris Gärtw. Ujdávidháza, Várpalánka, Nạ̣y-Lucska környékén ; Frigyesialván.

Buphthalmum salicifolimum L. A sík területen, Ujdávidházán.

Telekia speciosa (Schreb.) Baumg. A síkon Jejön egészen a Nyirses dülöig, Váralja mellett; Szidorfalva fölött, a Szinyákhegységben. Xanthium spinosum L. Várpalánka és Ujdávidháza legelöin kellemetlen gyom.

“ strumarium L. Várpalánka és Ujdávidháza kertjeiben és réteken.

Bidens cernua L. A Szernyemocsárban; a Csernapatak mentén a Szinyák heyységben; Beregszentmiklós és Frigyesfalva között; Klaesány körül. 
Bidens tripartita L. Ujdávidházán, a Latorcza mentén.

Rudbeckia hirta L. Réteken Munkács és Schönborn között, a Kerepeczpatak mentén.

Galinsoga parviflora CAvaiv. Ujdávidháza körül, kertekben és szántókon.

Anthemis arvensis L. A sik terïleten közönséges.

“ tinctoria L. A Lovácslán, Munkács mellett; Rákos és Ignécze között, az országút mentén.

Achillea Millefolium L. A sík területen közönséges.

Matricaria Chamonitla L. Ujđávidháza és Várpalánka környékén.

" discoidea DC. Volóczon és Vócsitelepen, az állomáson.

“ inodora L. Ujdảvidházán.

Chrysanthemum corymbosum L. A Lovácskán, Munkács mellett.

(i zönséges.

Leucanthemum L. A sík területen mindenütt kö-

vulgare L. A Latorcza partján, Várpalánka és Táralja között.

Artemisia Absynthium L. A sik teriileten, a Latorcza mentén mindeniitt.

" vulgaris L. A bejárt teriileten mindenütt.

“ campestris L. A Klastromalján, Munkács mellett; a Várhegyen, Várpalánka mellett.

Tussilago Farfara L. A sík teriileten, Munkács és Ujdávidháza közt a Latorcza mentén.

Petasites hybridus (L.) G. M. ScH. U'gyanott.

Erechthites hieracifolia (L.) RAF. A Pálhegy mögötti vágásban

Nunkács mellett.

Senecio barbareaefolius Krock. Ujdávidháza körül, a kukoriczásokban.

" erucifolius L. Ujdávidháza és Klacsány környékén.

" nemorensis L. A Sajgóban, Várkulesa mellett; a Szinyákhegységben.

" fuciatitis Wallr. Mocsaras helyeken a Sajgóban, Mezö terebes elött.

“ silvaticus L. Ilgóczon és Dunkófalván, a Szinyák-hegységbell.

" temuifolius JACQu. Dubróka kürnyékén.

“ viscosus L. Buboliska környékén, vágásokban, a Szinyákhegy ségben.

"vulgaris L. Mindeniitt a bejárt terïleten.

Echinops commutatus Juratzka. A sík terïleten, Ujdávidháza mellett.

Carlina acaulis L. var. alpina JACQU. A Szinyák-hegységben, Szarvasrét köriil.

“ longifolia Reichв. $t$. Grevibracteata Axdrae. Munkáes körül,

a szölöhegyeken; Szarvasréten, a Szinyák-hegységben.

" vulgaris L. Alsóvereczkén, a paplak fölötti hegyen. 
Arctium Lappa L Ujdávidházán és Várpalánkán.

" tomentosum MiLl. A sík teriileten közönséges.

Carduus acanthoides L. Szintén.

“ « " (usus albus). Várpalánkán, a temetö körül.

a Personata (L.) JACQU. Ujdávidháza és Várpalánka körüil.

Cirsium arvense (L.) Scop. A sik terïleten, vetések közt.

« horridum W. et Gr. Szintén.

" canum (L.) M. B. Rákos és Ujdávidháza körül.

“ palustre (L.) Sco`. Szarvasréten, a Szinyákhegységben.

Onopordon Acanthium L. Ujdávidházán; Várpalánkán a temetö körül.

Serratula tinctoria L. A Pálhegyen és Csernekhegyen, Munkács mellett, a Nagyhegyen, Beregszász mellett; a sik területen Mezöterebes, Barkaszó és Bátyú köriil.

" tinctoria L. (lusus albus). A Nagyhegyen, Beregszász mellett.

Centaurea austriaca WrLld. Felsővizniczén és Szarvasréten.

" Erdneri Wagn. (pseudophrygia $\times$ austriaca) Szarvasréten, a Szinyákhegységben; a Nagyhegyen, Beregszász mellett; a sík területen, Mezőterebes és Gorond körül.

“ extranea BЕск. Várpalánka kertjeiben igen gyéren.

“ jacea L. Ujdávidházán, réteken.

" Kupcsokiana WAGN. (oxylepis X rhenana) Korláthelmecz mellett; nagy mennyiségben Szobránczfürdő környékén, de már Ungmegyében; Ilgóczon, a szőlőhegyek alatt.

“ nigrescens WiLld. Gát mellett, a Feketevíz mentén.

" pannonica HeufF. Ujdávidházárı; Ilgóczon és Hegygombáson, a Szinyákhegységben; Váralja mellett, a Latolcza partján.

" similata Hausskn. (pseudophrygia $\times$ jacea) Ujdávidházán, a Latorcza partján.

" spuria Kerv. A Lovácskán és a Pálhegyen, Munkács mellett.

" pseudospinulosa Borı. A Nagyhegyen, Beregszász mellett.

“ Cyanus L. A sík területen vetések közt.

('ichorium Intybus L. A sik területen mindenütt.

Lapsana communis L. Ujdávidházán, kertekben.

Crepis biennis L. A sík területen közönséges.

" paludosa (L.) MNch. A sík teriileten, Ujdávidházán.

" setosa L. Ugyanott.

" virens L. Ugyanott.

Picris echioides L. A sík területen közönséges.

" Tatrae Borb. Ujdávidháza köriil. rétek árkaiban; a Nagyhegyen, Munkács mellett.

Hieracium Auicula DC. ssp. furcicula f. epilosum W. Várpalánkán, a Nagyhegyen, Beregszász mellett. 
Hieracium aurantiacum L. ssp. carpaticola NP. Szarvasréten, a Szinyák-hegységben.

" Bauhini Schult. Beregszászon a Nagyhegyen; Várpalánka környékén.

" leptopliylon IV. ssp. leptophyton NP. Beregszász köruil. " Pilosella L. ssp. brucunense N. P. Várpalánkán.

" matense Tauscir. $f$. brevipilum NP. Várpalánka és Munkács környékén.

" racemosum IV. et K. $f$. subracemosum ZaHn. A Csernekhegyen, Munkács mellett.

“ umbellatum L. Az Alföldet szegélyezö dombokon közönséges. Dubróka és Korláthelmecz közti dombokon.

" vulgatum Fr. 2. alpestre UEChTr. A Pikuj havason.

" " ssp. argillaceum Jond. Klacsány körül, az erdőkben.

Hypochaeris maculata L. Szarvasréten, a Szinyák-hegységben.

" radicata L. Ugyanott.

" " "var. hispida Petern. Ugyanott; a sík teriileten Mezöterebes köriil.

Leontodon autumnalis $\mathrm{L}$. A sík teriileten mindeniitt.

“ hispidus L. Szintén.

“ danubiulis JACQU. A Lovácskán, Munkács mellett.

Lactuca murulis I. A sík teriilet eldeiben.

" sagittata W. et $\mathrm{K}$. Várkulcsa és Mezöterebes közt az olszágút mentén: Ujdávidházán, a Latorcza partján.

"Scariola L. Ujdávidháza és Csongor köriil.

Prenanthes purpurea L. Szarvasréten, a Szinyák-hegységben.

Chondrilla juncea L. Ujdávidháza és Várpalánka közt, a Latorcza partján.

Sonchus asper (L.) Alt. Ilgóczon, a Szinyák-hegységben.

" laevis (L.) WiLl. A sík teriileten közönséges.

" arvensis L. Szintén.

Iragopogon orientalis L. A sík területen közönséges.

Tégiil ezuton is hálás köszönetet kell mondanom Dr DEgen Árpád, Dr. Gayer Gyula, Kupcsok Sanu, Dr. Szabó Zoltán és WÁGNer Jáxos uraknak, kik a legnagyobb készséggel határozták meg, illetre revideálták növényeimet. 
